\title{
KETEPATAN KLASIFIKASI PEMBERIAN KARTU KELUARGA SEJAHTERA DI KOTA SEMARANG MENGGUNAKAN METODE REGRESI LOGISTIK BINER DAN METODE CHAID
}

\author{
Muhammad Arif Suhendra ${ }^{1}$, Dra. Dwi Ispriyanti, M.Si ${ }^{2}$, Drs. Sudarno, M.Si ${ }^{3}$ \\ ${ }^{1,2,3}$ Departemen Statistika FSM Universitas Diponegoro \\ Email: dwiispriyanti@gmail.com
}

\begin{abstract}
ABSTRAK
Menurut BPS, jumlah penduduk miskin di Kota Semarang pada Maret 2018 adalah sebesar 73,65 ribu orang. Salah satu program pemerintah dalam percepatan penanggulangan kemiskinan adalah dengan mengeluarkan Kartu Keluarga Sejahtera (KKS) yang diberikan kepada masyarakat yang kurang mampu. Penelitian ini bertujuan untuk mengetahui besarnya ukuran ketepatan klasifikasi pemberian KKS di Kota Semarang. Metode klasifikasi statistik yang digunakan adalah metode Regresi Logistik Biner dan metode ChiSquared Automatic Interaction Detection (CHAID). Pemberian KKS dipengaruhi oleh banyak faktor, diantaranya jumlah anggota keluarga, status perkawinan, jenis kelamin kepala keluarga, usia kepala keluarga, jenjang pendidikan kepala keluarga dan kepemilikan/penguasaan HP. Pada penelitian ini, data yang digunakan adalah data sekunder hasil Survey Sosial Ekonomi Nasional (SUSENAS) tahun 2018 yang diperoleh dari Badan Pusat Statistik (BPS) Provinsi Jawa Tengah. Perbandingan data training dan testing yang digunakan adalah 60:40. Hasil analisisnya menunjukkan bahwa dengan menggunakan Regresi Logistik Biner, faktor-faktor yang berpengaruh adalah jumlah anggota keluarga dan jenjang pendidikan kepala keluarga dengan ketepatan klasifikasi sebesar $88 \%$ dan kesalahan 12\%, sedangkan dengan menggunakan CHAID, faktor-faktor yang berpengaruh adalah jumlah anggota keluarga, status perkawinan, usia kepala keluarga, jenjang pendidikan kepala keluarga dan kepemilikan/penguasaan HP dengan ketepatan klasifikasi sebesar 90,2\% dan kesalahan 9,8\%.
\end{abstract}

Kata kunci: Kartu Keluarga Sejahtera, Klasifikasi, Regresi Logistik Biner, CHAID

\section{PENDAHULUAN}

Kesejahteraan masyarakat merupakan suatu keadaan terpenuhinya kebutuhan material, spritual, dan sosial warga negara agar dapat hidup layak dan mampu mengembangkan diri, sehingga dapat melaksanakan fungsi sosialnya (UU No 11 Tahun 2009). Pada tahun 1997-1998, Indonesia dilanda sebuah krisis ekonomi terbesar yang Indonesia pernah alami sejak merdeka tahun 1945, yang dikenal dengan sebutan krisis keuangan Asia yang menyebabkan jumlah penduduk miskin di Indonesia bertambah banyak. Salah satu cara pemerintah menanggulangi kemiskinan di Indonesia yaitu dengan mengeluarkan Kartu Keluarga Sejahtera (KKS). Kartu Keluarga Sejahtera adalah salah satu program pemerintah dalam percepatan penanggulangan kemiskinan, hal ini tercantum pada Peraturan Presiden (Perpres) Nomor 166 Tahun 2014. Mengingat banyaknya kriteria dan jumlah masyarakat yang akan menerima KKS, maka akan membuat tim seleksi mengalami kesulitan dalam melakukan penyeleksian. Terlebih lagi apakah pemberian KKS kepada masyarakat sudah tepat sasaran atau belum. Maka dari itu diperlukan suatu alat bantu yang tepat untuk mengetahui ketepatan klasifikasi masyarakat yang menerima dan 
tidak menerima KKS tersebut. Metode klasifikasi dalam statistik yang dapat digunakan adalah metode CHAID dan metode regresi logistik biner.

Metode Chi-Squared Automatic Interaction Detection (CHAID) merupakan metode yang digunakan untuk menguji satu persatu variabel independen yang digunakan dalam klasifikasi, menggabungkan pasangan yang tidak signifikan dari variabel independen yang memilki 3 atau lebih kategori asal dan menyusunnya berdasarkan pada tingkat signifikansi statistik chi-square terhadap variabel dependennya (Gallagher, 2000).

Menurut Agresti (2002), metode regresi logistik biner merupakan metode yang digunakan untuk menganalisis faktor-faktor yang berpengaruh (variabel independen) terhadap KKS (variabel dependen) yang berupa data kualitatif dikotomi yang bernilai 1 untuk menyatakan keberadaan sebuah karakteristik (menerima KKS) dan bernilai 0 untuk menyatakan ketidakberadaan sebuah karakteristik (tidak menerima KKS). Metode regresi logistik biner menghasilkan model akhir yang nantinya digunakan untuk mengetahui ketepatan klasifikasinya.

\section{TINJAUAN PUSTAKA}

\subsection{Kartu Keluarga Sejahtera (KKS)}

Kartu Keluarga Sejahtera (KKS) merupakan salah satu program pemerintah di bidang sosial ekonomi untuk mempercepat penanggulangan kemiskinan nasional. Pada awalnya program tersebut adalah hasil dari pengembangan program sebelumnya yaitu Kartu Perlindungan Sejahtera (KPS). Fungsi KKS selain menjadi penanda masyarkat kurang mampu, juga berfungsi sebagai kartu identitas untuk mendapatkan Program Simpanan Keluarga Sejahtera (PSKS).

\subsection{Metode Regresi Logistik Biner}

Menurut Hosmer dan Lemeshow (2000) regresi logistik merupakan metode yang menghubungkan antara variabel dependen yang bersifat kategorik dengan variabel independen. Model regresi logistik dengan variabel dependen yang terdiri dari dua kategori disebut model regresi logistik biner (dikotomus). Model regresi logistik biner digunakan untuk menganalisis hubungan antara satu variabel dependen (Y) dengan satu atau lebih variabel independen $(\mathrm{X})$. Variabel dependennya berupa data kualitatif dikotomi yang bernilai 1 untuk menyatakan keberadaan sebuah karakteristik dan bernilai 0 untuk menyatakan ketidakberadaan sebuah karakteristik. Adapun bentuk model regresi logistiknya adalah sebagai berikut :

$$
\pi\left(x_{i}\right)=\frac{\exp \left(\beta_{0}+\beta_{1} x_{1 i}+\ldots .+\beta_{p} x_{p i}\right)}{1+\exp \left(\beta_{0}+\beta_{1} x_{1 i}+\ldots .+\beta_{p} x_{p i}\right)}
$$

Sedangkan logit dari $\pi\left(x_{i}\right)$ adalah

$$
g\left(x_{i}\right)=\ln \left[\frac{\pi\left(x_{i}\right)}{1-\pi\left(x_{i}\right)}\right]=\beta_{0}+\beta_{1} x_{1 i}+\ldots .+\beta_{p} x_{p i}
$$

\subsubsection{Uji Signifikansi Parameter}

Uji Signifkansi parameter yang digunakan adalah uji rasio Likelihood dan uji Wald.

1. Uji Rasio Likelihood

Uji Rasio Likelihood dilakukan untuk mengetahui signifikansi koefisien $\beta$ terhadap variabel dependen secara serentak (Hosmer dan Lemeshow, 2000). 
Hipotesis:

$\mathrm{H}_{0}: \beta_{1}=\beta_{2}=\cdots=\beta_{\mathrm{p}}=0$ (tidak ada pengaruh antara variabel independen dengan variabel dependennya)

$\mathrm{H}_{1}$ : paling sedikit ada satu $\beta_{\mathrm{j}} \neq 0$ dengan $\mathrm{j}=1,2, \ldots, \mathrm{p}$ (paling tidak ada satu variabel independen yang berpengaruh terhadap variabel dependennya)

Statistik Uji:

$\mathrm{G}=-2 \ln \left(\frac{\text { likelihood tanpa variabel bebas }}{\text { likelihood dengan variabel bebas }}\right)$

Kriteria Penerimaan: Terima $\mathrm{H}_{0}$ jika $\mathrm{G} \leq \chi_{(\mathrm{p}, \alpha)}^{2}$ dan terima $\mathrm{H}_{1}$ jika $\mathrm{G}>\chi_{(\mathrm{p}, \alpha)}^{2}$.

2. Uji Wald

Uji Wald dilakukan untuk mengetahui pengaruh setiap koefisien $\beta_{i}$ secara individual (Hosmer dan Lemeshow, 2000).

Hipotesis:

$\mathrm{H}_{0}: \beta_{\mathrm{j}}=0$ dengan $\mathrm{j}=1,2, \ldots, \mathrm{p}$ (tidak ada pengaruh antara variabel independen dengan variabel dependennya)

$\mathrm{H}_{1}: \beta_{\mathrm{j}} \neq 0$ dengan $\mathrm{j}=1,2, \ldots, \mathrm{p}$ (ada pengaruh antara variabel independen dengan variabel dependennya)

Statistik Uji:

$W_{j}=\left\{\frac{\widehat{\beta}_{J}}{\operatorname{se}\left(\widehat{\beta}_{J}\right)}\right\}^{2}$

Kriteria penerimaan: Terima $\mathrm{H}_{0}$ jika $W_{j} \leq \chi_{(\alpha, 1)}^{2}$ dan terima $\mathrm{H}_{1}$ jika $W_{j}>\chi_{(\alpha, 1)}^{2}$.

3. Uji Kesesuaian Model

Hosmer dan Lemeshow (2000) mengatakan bahwa uji kesesuaian model merupakan uji yang dilakukan untuk mengetahui apakah ada perbedaan antara prediksi dan hasil observasi (model sesuai atau tidak).

Hipotesis:

$\mathrm{H}_{0}$ : Model sesuai (tidak ada perbedaan antara hasil observasi dengan hasil prediksi)

$\mathrm{H}_{1}$ : Model tidak sesuai (ada perbedaan antara hasil observasi dengan hasil prediksi)

Statistik Uji:

$\hat{C}=\sum_{k=1}^{g} \frac{\left(o_{k}-n_{k}^{\prime} \overline{\pi_{k}}\right)^{2}}{\left(n_{k}^{\prime} \overline{\pi_{k}}\right)\left(1-\overline{\pi_{k}}\right)}$

dengan:

$o_{k}$ : Jumlah nilai variabel respon pada grup ke- $k$

$\frac{k}{\pi_{k}}$ : Rata-rata taksiran peluang pada grup ke- $k$

$g:$ Banyak grup

$n_{k}^{\prime}$ : Banyak observasi pada grup ke- $k$

Kriteria penerimaan: Terima $\mathrm{H}_{0}$ jika $\hat{C} \leq \chi_{(\alpha, g-2)}^{2}$ dan terima $\mathrm{H}_{1}$ jika $\hat{C}>\chi_{(\alpha, g-2)}^{2}$.

\subsection{Metode CHAID}

CHAID pertama kali diperkenalkan dalam sebuah artikel berjudul "An Exploratory Technique for Investigating Large Quantities of Categorical Data” oleh Dr.G.V.Kass tahun 1980. Prosedurnya merupakan bagian dari teknik terdahulu yang dikenal dengan Automatic Interaction Detector (AID) dan menggunakan statistik chi-square sebagai alat 
utamanya. Analisis CHAID secara garis besar dibagi menjadi tiga tahap yaitu penggabungan, pemisahan dan penghentian.

\subsubsection{Variabel-variabel dalam Analisis CHAID}

Variabel dependen dan independen dalam analisis CHAID adalah variabel kategorik. Menurut Gallagher (2000), CHAID akan membedakan variabel-variabel independen kategorik menjadi tiga bentuk yang berbeda, yaitu:

1. Monotonik yaitu variabel independen yang kategori di dalamnya dapat dikombinasikan atau digabungkan oleh CHAID hanya jika keduanya berdekatan satu sama lain atau mengikuti urutan aslinya (data ordinal). Contoh: usia dan pendapatan.

2. Bebas yaitu variabel independen yang kategori di dalamnya dapat dikombinasikan atau digabungkan ketika keduanya berdekatan ataupun tidak (data nominal). Contoh: pekerjaan,kelompok etnik dan area geografis.

3. Mengambang (floating) yaitu variabel independen yang kategori di dalamnya dapat diperlakukan seperti monotonik kecuali untuk kategori yang missing value, yang dapat dikombinasikan dengan kategori manapun.

\subsubsection{Uji Chi-Square (Independensi)}

Langkah-langkah dalam melakukan uji chi-square adalah sebagi berikut:

Hipotesis:

$\mathrm{H}_{0}$ : kedua kriteria klasifikasi bebas (independen)

$\mathrm{H}_{1}$ : kedua kriteria klasifikasi tidak bebas (dependen)

Statistik uji:

$$
\begin{gathered}
\chi_{\text {hitung }}^{2}=\sum_{i=1}^{r} \sum_{j=1}^{c}\left[\frac{\left(n_{i j}-E_{i j}\right)^{2}}{E_{i j}}\right] \\
E_{i j}=\frac{n_{i . n} \cdot j}{n}
\end{gathered}
$$

Kriteria penerimaan: Terima $\mathrm{H}_{0}$ jika $\chi_{\text {hitung }}^{2} \leq \chi_{\alpha:(r-1)(c-1)}^{2}$ dan terima $\mathrm{H}_{1}$ jika $\chi_{\text {hitung }}^{2}>\chi_{\alpha:(r-1)(c-1)}^{2}$.

\subsubsection{Koreksi Bonferroni}

Pengurangan kategori pada tahap penggabungan algoritma CHAID dibutuhkan uji signifikansi. Ketika terjadi pengurangan yaitu c kategori variabel asal menjadi $r$ kategori (c $>$ r), maka tingkat kesalahan $\left(\alpha_{i}\right)$ dikalikan dengan pengali Bonferroni sesuai dengan tipe variabelnya. Gallagher (2000) menyebutkan bahwa pengali Bonferroni untuk masingmasing jenis variabel-variabel independen adalah sebagai berikut:

1. Variabel independen monotonik

2. Variabel independen bebas

$$
\mathrm{M}=\left(\begin{array}{l}
c-1 \\
r-1
\end{array}\right)
$$

$$
\mathrm{M}=\sum_{i=0}^{r-1}(-1)^{i} \frac{(r-i)^{c}}{i !(r-i) !}
$$

3. Variabel independen mengambang (floating)

$$
\mathrm{M}=\left(\begin{array}{l}
c-2 \\
r-2
\end{array}\right)+r\left(\begin{array}{l}
c-2 \\
r-1
\end{array}\right)
$$




\subsubsection{Algoritma CHAID}

a. Tahap Penggabungan

1. Membentuk tabel kontingensi dua arah untuk masing-masing variabel independen dengan variabel dependennya.

2. Menghitung statistik chi-square untuk setiap pasang kategori yang dapat dipilih untuk digabungkan menjadi satu

3. Di antara pasangan-pasangan yang tidak signifikan, gabungkan sebuah pasangan kategori yang paling mirip (yaitu pasangan yang mempunyai nilai chi-square terkecil dan p-value terbesar) menjadi sebuah kategori tunggal dari variabel independen yang mempunyai 3 atau lebih kategori asal.

4. Memeriksa kembali signifikansi kategori baru setelah penggabungan dengan kategori lainnya dalam variabel independen. Jika ada pasangan yang belum signifikan, maka ulangi langkah 3. Jika semua langkah sudah signifikan, maka lanjutkan ke langkah berikutnya.

5. Menghitung p-value terkoreksi Bonferroni didasarkan pada tabel yang sudah digabungkan.

b. Tahap Pemisahan

Memilih variabel independen terbaik, yaitu variabel independen dengan nilai pvalue terkecil, kemudian melakukan pembagian kelompok dengan variabel independen (yaitu gunakan masing-masing kategori-kategori variabel independen tersebut, yang telah digabungkan secara optimal, untuk menentukan sub pembagian dari kelompok induk menjadi sub kelompok yang baru). Jika tidak ada variabel independen dengan nilai p-value yang signifikan, jangan memulai pembagian kelompok tersebut.

c. Tahap Penghentian

Tahap penghentian dilakukan ketika pertumbuhan pohon harus dihentikan. Menurut Rokach dan Maimon (2008), penyekatan simpul dalam pembentukan pohon harus dihentikan karena:

1. Pada simpul hanya terdapat kasus yang berasal dari salah satu kelas variabel dependen.

2. Kedalaman pohon maksimal telah tercapai.

3. Jumlah kasus di simpul terminal kurang dari jumlah minimal kasus untuk menjadi simpul orang tua (parent node).

4. Jika simpul disekat, jumlah kasus dalam satu atau lebih simpul anak akan kurang dari jumlah minimal kasus untuk simpul anak, maka proses penyekatan simpul berhenti.

5. Jika semua variabel independen mempunyai nilai signifikansi lebih besar dari nilai alpha yang ditentukan, maka simpul tidak dapat disekat.

\subsection{Ketepatan Klasifikasi}

Menurut Johnson dan Wichern (1992), prosedur klasifikasi yang bisa digunakan untuk mengukur ketepatan klasifikasi adalah Apparent Error Rate (APER). Nilai APER menyatakan proporsi sampel yang salah diklasifikasikan oleh fungsi klasifikasi. Kesalahan klasifikasi dapat dilihat pada tabel matriks konfusi berikut: 
Tabel 1. Matriks Konfusi

\begin{tabular}{|c|c|c|}
\hline \multirow{2}{*}{ Hasil Observasi } & \multicolumn{2}{|c|}{ Taksiran } \\
\cline { 2 - 3 } & $y_{1}$ & $y_{2}$ \\
\hline$y_{1}$ & $n_{11}$ & $n_{12}$ \\
\hline$y_{2}$ & $n_{21}$ & $n_{22}$ \\
\hline
\end{tabular}

Maka nilai APER dapat dihitung dengan rumus:

$\mathrm{APER}=\frac{n_{12}+n_{21}}{n_{11}+n_{12}+n_{21}+n_{22}}$

Akurasi $=1-$ APER

\section{METODE PENELITIAN}

\subsection{Jenis dan Sumber Data}

Jenis data yang digunakan dalam penelitian ini adalah data sekunder yaitu data hasil Survei Sosial Ekonomi Nasional (SUSENAS) di Kota Semarang Tahun 2018. Adapun data tersebut diperoleh dari Badan Pusat Statistik (BPS) Provinsi Jawa Tengah.

\subsection{Variabel Penelitian}

Variabel pada penelitian ini terdiri dari variabel dependen (Y) dan beberapa variabel independen (X). Adapun varibel-variabel tersebut adalah sebagai berikut:

1. Variabel Dependen $\mathrm{Y}=\mathrm{KKS}, 0$ = tidak menerima KKS, $1=$ menerima $\mathrm{KKS}$

2. Variabel Independen

$\mathrm{X} 1$ = jumlah anggota keluarga, $\mathrm{X} 2=$ status perkawinan, $\mathrm{X} 3=$ jenis kelamin kepala keluarga, X4 = usia kepala keluarga, X5 = jenjang pendidikan kepala keluarga, X6 = kepemilikan/penguasaan HP

\subsection{Teknik Pengolahan Data}

Pada penelitian ini, analisis yang digunakan menggunakan metode regresi logistik biner dan metode CHAID. Adapun software yang digunakan sebagai alat bantu dalam menganalisis yaitu Microsoft Excel 2007 dan IBM SPSS Statistics 23.

1. Tahapan analisis data metode regresi logistik biner adalah sebagai berikut :

a. Memasukkan data KKS sebagai variabel dependen dan jumlah anggota keluarga, status perkawinan, jenis kelamin kepala keluarga, usia kepala keluarga, , jenjang pendidikan tertinggi kepala keluarga, dan kepemilikan HP sebagai variabel independen.

b. Membagi data menjadi data training dan data testing.

c. Menghitung estimasi parameter menggunakan data training untuk mendapatkan model awal.

d. Melakukan uji likelihood untuk mengetahui apakah variabel independen secara bersama-sama mempengaruhi variabel dependennya.

e. Melakukan uji Wald untuk mengetahui ada atau tidaknya pengaruh masingmasing variabel independen terhadap variabel dependennya.

f. Melakukan uji kesesuaian model.

g. Menentukan model akhir.

h. Menghitung ketepatan klasifikasi model menggunakan data testing. 
2. Tahapan analisis data menggunakan metode CHAID

a. Memasukkan data KKS sebagai variabel dependen dan jumlah anggota keluarga, status perkawinan, jenis kelamin kepala keluarga, usia kepala keluarga, jenjang pendidikan tertinggi kepala keluarga, dan kepemilikan HP sebagai variabel independen.

b. Membagi data menjadi data training dan data testing.

c. Melakukan tabulasi silang antara variabel independen dan variabel dependennya menggunakan data testing.

d. Melakukan penggabungan terhadap kategori-kategori penggabungan dalam variabel independen yang memiliki nilai chi-square terkecil.

e. Pemilihan variabel independen yang mempunyai nilai p-value terkecil sebagai pemisah untuk membentuk sub kelompok. Proses pemilihan variabel untuk memisah terus berjalan hingga peraturan penghentian yang diberlakukan.

f. Menginterpretasikan pohon klasifikasi yang terbentuk.

g. Menghitung nilai ketepatan klasifikasi.

\section{HASIL DAN PEMBAHASAN}

\subsection{Analisis Data Menggunakan Regresi Logistik Biner}

Berdasarkan pengolahan data didapat model regresi logistik biner. Berikut adalah model yang dihasilkan:

$\pi\left(x_{i}\right)=\frac{\mathrm{e}^{\mathrm{g}\left(\mathrm{x}_{\mathrm{i}}\right)}}{1+\mathrm{e}^{\mathrm{g}\left(\mathrm{x}_{\mathrm{i}}\right)}}$

dengan

$$
\begin{gathered}
g\left(x_{i}\right)=-4,554+0,894 X_{1(1)}-17,901 X_{2(1)}-0,173 X_{2(2)}-0,142 X_{3(1)}- \\
0,227 X_{4(1)}+2,728 X_{5(1)}+1,560 X_{5(2)}+0,227 X_{6(1)}
\end{gathered}
$$

\subsubsection{Uji Rasio Likelihood}

Hipotesis

$\mathrm{H}_{0}: \beta_{1}=\beta_{2}=\cdots=\beta_{8}=0$

$\mathrm{H}_{1}$ : paling sedikit ada satu $\beta_{\mathrm{j}} \neq 0$ dengan $\mathrm{j}=1,2, \ldots, 8$

Taraf Signifikansi $\alpha=5 \%$

Statistik Uji:

$\mathrm{G}=-2 \ln \left(\frac{\text { likelihood tanpa variabel bebas }}{\text { likelihood dengan variabel bebas }}\right)=31,947$

Nilai $G>\chi_{(8 ; 0,05)}^{2}$ yaitu $31,947>15,507$ maka $\mathrm{H}_{1}$ diterima sehingga paling sedikit ada satu variabel independen yang memberikan pengaruh terhadap variabel dependennya.

\subsubsection{Uji Wald}

Hipotesis

$\mathrm{H}_{0}: \beta_{\mathrm{j}}=0$ dengan $\mathrm{j}=1,2, \ldots, 8$

$\mathrm{H}_{1}: \beta_{\mathrm{j}} \neq 0$ dengan $\mathrm{j}=1,2, \ldots, 8$

Taraf signifikansi $\alpha=5 \%$

Statistik uji Wald:

$W_{j}=\left\{\frac{\widehat{\beta}_{J}}{\operatorname{se}\left(\widehat{\beta}_{J}\right)}\right\}^{2}$ 
Berdasarkan output regresi logistik biner dapat dibentuk tabel 2 sebagai berikut:

Tabel 2. Hasil Uji Wald Model Awal

\begin{tabular}{|l|c|c|c|c|}
\hline \multicolumn{1}{|c|}{ Variabel } & Koefisien & SE Koefisien & Wald & p-value \\
\hline Jumlah_AK(1) & 0.894 & 0.382 & 5.477 & 0.019 \\
\hline Status(1) & -17.901 & 6814.356 & 0.000 & 0.998 \\
\hline Status(2) & -0.173 & 0.806 & 0.046 & 0.830 \\
\hline JK(1) & -0.142 & 0.820 & 0.030 & 0.863 \\
\hline Usia(1) & -0.227 & 0.392 & 0.334 & 0.563 \\
\hline Pendidikan(1) & 2.728 & 1.038 & 6.904 & 0.009 \\
\hline Pendidikan(2) & 1.560 & 1.064 & 2.148 & 0.143 \\
\hline HP(1) & 0.227 & 0.428 & 0.280 & 0.597 \\
\hline Constant & -4.554 & 1.109 & 16.866 & 0.000 \\
\hline
\end{tabular}

Berdasarkan tabel 2, nilai $W_{j}>\chi_{(0,05 ; 1)}^{2}$ untuk variabel jumlah anggota keluarga $\left(\mathrm{X}_{1}\right)$ dan jenjang pendidikan tertinggi kepala keluaga $\left(\mathrm{X}_{5}\right)$ sehingga kedua variabel tersebut signifikan terhadap model. Karena terdapat beberapa variabel independen yang tidak signifikan maka akan dibentuk model baru dengan tidak mengikutsertakan variabel-variabel yang tidak signifikan tersebut.

\subsubsection{Uji Kesesuaian Model}

Hipotesis

$\mathrm{H}_{0}$ : Model sesuai (tidak ada perbedaan antara hasil observasi dengan hasil prediksi)

$\mathrm{H}_{1}$ : Model tidak sesuai (ada perbedaan antara hasil observasi dengan hasil prediksi)

Taraf signifikansi $\alpha=5 \%$

Statistik uji:

$\widehat{\mathrm{C}}=\sum_{\mathrm{k}=1}^{\mathrm{g}} \frac{\left(\mathrm{o}_{\mathrm{k}}-\mathrm{n}_{\mathrm{k}}^{\prime} \overline{\pi_{\mathrm{k}}}\right)^{2}}{\left(\mathrm{n}_{\mathrm{k}}^{\prime} \overline{\pi_{\mathrm{k}}}\right)\left(1-\overline{\pi_{\mathrm{k}}}\right)}=2,488$

Nilai $\widehat{C} \leq \chi_{(0,05 ; 4)}^{2}$ yaitu $2,488<9,488$ maka $\mathrm{H}_{0}$ diterima sehingga dapat disimpulkan model sesuai (tidak ada perbedaan antara hasil observasi dengan hasil prediksi).

\subsubsection{Model Akhir}

$$
\begin{aligned}
& \pi\left(x_{i}\right)=\frac{\mathrm{e}^{\mathrm{g}\left(\mathrm{x}_{\mathrm{i}}\right)}}{1+\mathrm{e}^{\mathrm{g}\left(\mathrm{x}_{\mathrm{i}}\right)}} \\
& \text { dengan } \\
& \mathrm{g}\left(\mathrm{x}_{\mathrm{i}}\right)=-5.051+0,876 \mathrm{X}_{1(1)}+2.935 \mathrm{X}_{5(1)}+1.736 \mathrm{X}_{5(2)}
\end{aligned}
$$

\subsubsection{Ketepatan Klasifikasi}

Tabel 3. Matriks Konfusi Regresi Logistik Biner

\begin{tabular}{|l|c|c|}
\hline \multirow{2}{*}{\multicolumn{1}{|c|}{ Observasi }} & \multicolumn{2}{|c|}{ Prediksi } \\
\cline { 2 - 3 } & Tidak menerima KKS & Menerima KKS \\
\hline Tidak menerima KKS & 324 & 0 \\
\hline Menerima KKS & 44 & 0 \\
\hline
\end{tabular}

$$
\begin{aligned}
\text { APER } & =\frac{0+44}{324+0+44+0} \\
& =0,120
\end{aligned}
$$




$$
\begin{aligned}
\text { Akurasi } & =1-\text { APER } \\
& =1-0,120 \\
& =0,88 \\
& =88 \%
\end{aligned}
$$

\subsection{Analisis Data Menggunakan CHAID}

\subsubsection{Tahap Penggabungan}

Pada penelitian ini, variabel independen yang mengalami proses penggabungan adalah variabel status perkawinan dan jenjang pendidikan kepala keluarga. Adapun hasil uji statistik chi-squarenya adalah sebagai berikut:

Tabel 4. Nilai Statistik Chi-Square

\begin{tabular}{|c|c|c|c|c|}
\hline \multirow{3}{*}{ Variabel } & Definisi & Kategori & $\begin{array}{c}\text { Chi- } \\
\text { Square }\end{array}$ & Keputusan \\
\hline \multirow{3}{*}{$\mathrm{X}_{2}$} & \multirow{3}{*}{ Status Perkawinan } & Belum Kawin (1) dan Kawin (2) & 1,411 & $\mathrm{H}_{0}$ diterima \\
\cline { 3 - 5 } & & Belum Kawin (1) dan Cerai (3) & 5,227 & $\mathrm{H}_{0}$ ditolak \\
\cline { 3 - 5 } & & Kawin (2) dan Cerai (3) & 7,098 & $\mathrm{H}_{0}$ ditolak \\
\hline \multirow{2}{*}{$\mathrm{X}_{5}$} & $\begin{array}{c}\text { Pendidikan Kepala } \\
\text { keluarga }\end{array}$ & $<$ SMA (1) dan SMA (2) & 12,751 & $\mathrm{H}_{0}$ ditolak \\
\cline { 3 - 5 } & & SMA (2) dan >SMA (3) & 3,447 & $\mathrm{H}_{0}$ diterima \\
\hline
\end{tabular}

Dari tabel 4 diperoleh hasil bahwa $\mathrm{H}_{0}$ diterima untuk variabel status perkawinan kategori belum kawin (1) dan kawin (2) dan variabel pendidikan kepala keluarga kategori SMA (2) dan >SMA (3) sehingga dapat disimpulkan kategori-kategori tersebut saling bebas (tidak signifikan). Maka kategori-kategori tersebut perlu digabungkan menjadi sebuah kategori tunggal. Selanjutnya dilakukan pengujian yang sama untuk kategori gabungan dengan kategori lainnya dan didapatkan hasil bahwa kedua kategori tersebut sudah signifikan sehingga penggabungan telah maksimal.

$>$ Pengali Bonferroni untuk variabel status perkawinan

$$
\begin{aligned}
\mathrm{M}=\sum_{i=0}^{r-1}(-1)^{i} \frac{(r-i)^{c}}{i !(r-i) !}= & {\left[(-1)^{0} \frac{(2-0)^{3}}{0 !(2-0) !}\right]+\left[(-1)^{1} \frac{(2-1)^{3}}{1 !(2-1) !}\right] } \\
=4 & -1 \\
=3 &
\end{aligned}
$$

Uji signifikansi terkoreksi $=0,006 \times 3=0,018$. Karena $0,018<0,05$ maka dapat disimpulkan bahwa variabel status perkawinan (belum kawin;kawin dan cerai) signifikan (tidak saling bebas) terhadap variabel KKS.

$>$ Pengali Bonferroni untuk variabel pendidikan

$$
\mathrm{M}=\left(\begin{array}{l}
c-1 \\
r-1
\end{array}\right)=\left(\begin{array}{l}
3-1 \\
2-1
\end{array}\right)=\frac{2 !}{1 !(2-1) !}=2
$$

Uji signifikansi terkoreksi $=0,000 \times 2=0$. Karena $0,00<0,05$ maka dapat disimpulkan bahwa variabel jenjang pendidikan tertinggi kepala keluarga (<SMA dan SMA;>SMA) signifikan (tidak saling bebas) terhadap variabel KKS.

\subsubsection{Tahap Pemisahan}

Tahap pemisahan adalah tahap memilih variabel independen mana yang akan digunakan sebagai simpul pemisah terbaik. Simpul pemisah terbaik merupakan variabel independen yang memiliki nilai chi-square terbesar atau nilai p-value terkecil. 
Tabel 5. Uji Chi-Square Tahap Pemisahan Simpul Akar $\left(t_{0}\right)$

\begin{tabular}{|c|c|c|c|c|c|}
\hline Variabel & Definisi & Kategori & $\begin{array}{c}\text { Chi- } \\
\text { Square }\end{array}$ & Keputusan & Kesimpulan \\
\hline \multirow{2}{*}{$\mathrm{X}_{1}$} & \multirow{2}{*}{$\begin{array}{l}\text { Jumlah Anggota } \\
\text { Keluarga }\end{array}$} & $>4(1)$ & \multirow{2}{*}{0,171} & \multirow{2}{*}{$\mathrm{H}_{0}$ diterima } & \multirow{2}{*}{$\begin{array}{c}\text { Tidak } \\
\text { signifikan }\end{array}$} \\
\hline & & $<=4(2)$ & & & \\
\hline \multirow{2}{*}{$X_{2}$} & \multirow{2}{*}{ Status Perkawinan } & Belum Kawin;Kawin (1) & \multirow{2}{*}{8,467} & \multirow{2}{*}{$\mathrm{H}_{1}$ diterima } & \multirow{2}{*}{ Signifikan } \\
\hline & & Cerai (2) & & & \\
\hline \multirow{2}{*}{$X_{3}$} & \multirow{2}{*}{$\begin{array}{c}\text { Jenis Kelamin Kepala } \\
\text { Keluarga }\end{array}$} & Laki-laki (1) & \multirow{2}{*}{0,838} & \multirow{2}{*}{$\mathrm{H}_{0}$ diterima } & \multirow{2}{*}{$\begin{array}{c}\text { Tidak } \\
\text { signifikan }\end{array}$} \\
\hline & & Perempuan (2) & & & \\
\hline \multirow{2}{*}{$\mathrm{X}_{4}$} & \multirow{2}{*}{$\begin{array}{c}\text { Usia Kepala Rumah } \\
\text { Tangga }\end{array}$} & $>54(1)$ & \multirow{2}{*}{0,384} & \multirow{2}{*}{$\mathrm{H}_{0}$ diterima } & \multirow{2}{*}{$\begin{array}{c}\text { Tidak } \\
\text { signifikan }\end{array}$} \\
\hline & & $<=54(2)$ & & & \\
\hline \multirow{2}{*}{$X_{5}$} & \multirow{2}{*}{$\begin{array}{c}\text { Jenjang Pendidikan } \\
\text { Tertinggi Kepala } \\
\text { Keluarga }\end{array}$} & $<$ SMA (1) & \multirow{2}{*}{26,454} & \multirow{2}{*}{$\mathrm{H}_{1}$ diterima } & \multirow{2}{*}{ Signifikan } \\
\hline & & SMA;>SMA (2) & & & \\
\hline \multirow{2}{*}{$X_{6}$} & \multirow{2}{*}{$\begin{array}{l}\text { Kepemilikan/ } \\
\text { Penguasaan HP }\end{array}$} & $\begin{array}{c}\text { Tidak memiliki/menguasai } \\
\text { HP (1) }\end{array}$ & \multirow{2}{*}{47,540} & \multirow{2}{*}{$\mathrm{H}_{1}$ diterima } & \multirow{2}{*}{ Signifikan } \\
\hline & & $\begin{array}{c}\text { Memiliki/menguasai } \\
\text { HP (2) }\end{array}$ & & & \\
\hline
\end{tabular}

Tabel 5 menunjukkan bahwa variabel kepemilikan/penguasaan HP merupakan variabel pemilah terbaik pada simpul akar $\left(t_{0}\right)$ karena mempunya nilai chi-square terbesar yaitu 47,540. Proses pemilahan terus dilakukan pada setiap simpul selama masih terdapat variabel-variabel independen yang signifikan.

\subsubsection{Tahap Penghentian}

Tahap pemberhentian terjadi pada simpul pendidikan kepala keluarga kategori $<$ SMA, pendidikan kepala keluarga kategori $\geq$ SMA, jumlah anggota keluarga $\leq 4$, jumlah anggota keluarga $>4$, status perkawinan kategori (belum kawin;kawin) dan simpul status perkawinan kategori (cerai). Hal tersebut terjadi karena disebabkan hal berikut:

1. Proses pemberhentian terjadi pada simpul pendidikan kepala keluarga kategori $<$ SMA, pendidikan kepala keluarga kategori $\geq$ SMA, jumlah anggota keluarga $\leq 4$, status perkawinan kategori (belum kawin;kawin) dan simpul status perkawinan kategori (cerai) disebabkan karena sudah tidak ada lagi variabel independen yang signifikan.

2. Proses pemberhentian terjadi pada simpul jumlah anggota keluarga $>4$ disebabkan karena jumlah kasus di simpul tersebut kurang dari jumlah minimum untuk menjadi simpul orang tua (parent node) yaitu 6.

\subsubsection{Ketepatan Klasifikasi}

Tabel 6. Matriks Konfusi CHAID

\begin{tabular}{|l|c|c|}
\hline \multirow{2}{*}{ Observasi } & \multicolumn{2}{|c|}{ Prediksi } \\
\cline { 2 - 3 } & Tidak Menerima KKS & Menerima KKS \\
\hline Tidak Menerima KKS & 319 & 5 \\
\hline Menerima KKS & 31 & 13 \\
\hline
\end{tabular}

$$
\begin{aligned}
& \text { APER }=\frac{31+5}{319+5+31+13}=0,098 \\
& \begin{aligned}
\text { Akurasi } & =1-\text { APER } \\
& =0,902 \\
& =90,2 \%
\end{aligned}
\end{aligned}
$$




\section{KESIMPULAN}

Berdasarkan hasil dan pembahasan dapat diambil kesimpulan sebagai berikut:

1. Faktor-faktor yang mempengaruhi pemberian KKS di Kota Semarang dengan menggunakan metode regresi logistik biner adalah variabel jumlah anggota keluarga dan pendidikan kepala keluarga, sedangkan dengan menggunakan metode CHAID diperoleh hasil bahwa yang berpengaruh adalah variabel jumlah anggota keluarga, status perkawinan, usia kepala keluarga, pendidikan kepala keluarga dan kepemilikan/penguasaan HP.

2. Nilai akurasi pengklasifikasian pemberian KKS di Kota Semarang menggunakan regresi logistik biner adalah $88 \%$ dengan nilai APER 12\%, sedangkan dengan menggunakan CHAID diperoleh nilai akurasi sebesar 90,2\% dengan nilai APER $9,8 \%$.

3. Dari hasil perbandingan ketepatan klasifikasi menggunakan metode regresi logistik biner dan CHAID diperoleh hasil bahwa metode CHAID lebih baik daripada metode regresi logistik biner dalam pengklasifikasian pemberian KKS di Kota Semarang.

\section{DAFTAR PUSTAKA}

Agresti, A. (2002). Categorial Data Analysis Second Edition. New York: John Willey and Sons.

Gallagher, C.A. (2000). An Iterative Approach to Classification Analysis. https://www.casact.org/pubs/dpp/dpp90/90dpp237.pdf. (Diakses pada Juli 2019)

Hosmer, D.W., dan Lemeshow. (2000). Applied Logistic Regression. USA: John Willey and Sons.

Johnson, R. A., dan Winchern. (2007). Applied Multivariate Statistical Analysis. New Jersey: Prentice Hall International, Inc.

Kass, G.V. (1980). An Exploratory Technique for Invertigating Large Quantities of Categorical Data. Applied Statistical 29, No. 2; 119-127.

Rokach, L., dan Maimon, O. (2008). Data Mining with Decision Trees "teory and Application". USA : World Scientific Publishing Co. Pte. Ltd.

Undang-Undang Republik Indonesia Tahun 2009 Tentang Kesejahteraan Sosial. 